\title{
ASPERGILLUS FLA VUS INFECTION AND AFLATOXIN CONTAMINATION IN PEANUTS AT VARIOUS STAGES OF THE DELIVERY CHAINS IN CIANJUR REGENCY, WEST JAVA, INDONESIA
}

\author{
OKKYSETYAWATIDHARMAPUTRA \\ SEAMEO BIOTROP, P.O. Box 116, Bogor 16001, Indonesia, \\ and Department of Biology, Faculty of Mathematics and Natural Sciences, \\ Bogor Agricultural University, Bogor, Indonesia
}

INA RETNOWATI, SANTI AMBARWATI and ERITA MAYSRA SEAMEO BIOTROP, P.O. BOX

116, Bogor 16001, Indonesia

\begin{abstract}
A survey to obtain information on pre- and postharvest handling of peanuts at farmer, collector, wholesaler and retailer levels, including Aspergillus flavus infection and aflatoxin BI contamination of peanuts collected in Cianjur regency, West Java, was conducted during the harvest period of the wet season of February 2004. The moisture contents and physical qualities of the peanuts were also determined.

Thirteen and 40 dry pod samples were collected randomly from 12 farmers and 23 collectors, respectively. Seven dry kernel samples were also collected from collectors. Five and 45 dry kernel samples were collected randomly from 2 wholesalers and 45 retailers in traditional markets, respectively. Thus, a total of 110 dry peanut pod and kernel samples were collected.

The results of interviews with farmers, collectors, wholesalers and retailers, and also the moisture contents and physical qualities of the peanuts arc described in this article.

The percentages of samples infected by A. flavus were highest at the wholesaler as well as at retailer levels (100\%, respectively), followed by those sampled at the collectors ( 85.0 and $85.7 \%$, respectively), and farmers (84.6\%). The mean percentage of infected kernels in infected samples of peanuts collected from retailers was the highest (87.6\%), followed by those collected from wholesalers (72.4\%), collectors in the form of kernels (23.3\%) and pods (17.7\%), and farmers (15.2\%).

The range of aflatoxin BI contents in peanut samples collected from farmers (dry pods), collectors (dry pods), wholesalers (dry pods and kernels) and retailers (dry kernels) were $<3.6$-114.2, $<3.6-2999.5$ and $<3,6-34.1,<3.6$ 6065.9 , and $<3.6-6073.0 \mathrm{ppb}$, respectively. The highest aflatoxin B, contents at the wholesaler and retailer levels were $6065.9 \mathrm{ppb}$ (in one sample) and $6073.0 \mathrm{ppb}$ (in one sample), respectively. The percentage of samples contaminated with more than $15 \mathrm{ppb}$ of aflatoxin BI was the highest in peanuts collected from wholesalers ( $80.0 \%$ of samples), followed by retailers (75.6\%), farmers (38.5\%) and collectors (30.0 and 14.3\%). In 1999 Codex Alimcntarius Commission determined that the maximum total aflatoxin content in peanuts intended for further processing is $15 \mathrm{ppb}$, suggesting that an alarming proportion of peanuts throughout the Indonesian food chain arc in excess of this maximum limit.
\end{abstract}

Key words : ,4,spergillius flavus/Aflatoxin/Peanuts/Cianjur regency

\section{INTRODUCTION}

Peanuts are next to maize and soybean as the most important secondary crop in Indonesia. Since Indonesia has a humid tropical climate, peanuts can easily be 
infected by moulds (including A. flavus) under drought stress before harvest, during the drying phase in the field, or under poor storage conditions. Aflatoxin has been recognized as a human and domestic animal carcinogen, and is produced following infection of peanuts by certain strains of $A$. flavus.

Pitt and Hocking (1996) reported that $45 \%$ of 215 peanut samples collected from farm storage, middlemen and retailers in Bogor (West Java), Yogyakarta (Central Java), and their surroundings, contained more than $50 \mathrm{ppb}$ of aflatoxin, 33\% more than $300 \mathrm{ppb}$, and $22 \%$ exceeded $1000 \mathrm{ppb}$.

The total annual cost of aflatoxins in peanuts in 1991 in Indonesia, Philippines and Thailand was estimated as about \$ A 158 million. Indonesia incurred 84\% (= \$ A 132 million) of this cost (Lubulwa and Davis 1994).

According to Dharmaputra et al. (2003a), in general, aflatoxin BI contents of peanuts collected from farmer's fields/pewefoas/collectors and processed samples in the Pati regency of Central Java were low (less than $15 \mathrm{ppb}$ ). The highest aflatoxin $\mathrm{B} \mid$ contents were found in raw peanut kernels collected from retailers in traditional markets, ranging from 2-124 and $<4$ - 342 ppb during the wet and dry seasons in 2002, respectively. The percentage of raw kernel samples contaminated with aflatoxin BI (exceeding $15 \mathrm{ppb}$ ) collected during the wet and dry seasons was 33 and $25 \%$, respectively.

Another study was also carried out by Dharmaputra et al. (2005) on aflatoxin BI contents of peanuts collected from farmer's fields, collectors and retailers in the Wonogiri regency and specifically the city of Surakarta (Central Java) during the wet and dry seasons in 2003. The results also showed that the highest aflatoxin $\mathrm{B}$, contents were found in raw peanut kernels collected from retailers in traditional markets, with the range of $<3.6-1859.3$ and $<3.6-5511.5$ $\mathrm{ppb}$ during the wet and dry seasons, respectively. The percentage of raw kernel samples contaminated with aflatoxin BI (exceeding $15 \mathrm{ppb}$ ) collected during the wet and dry seasons was 33 and $76 \%$, respectively.

The $23^{\text {rd }}$ session of the Joint FAO/WHO Food Standards Programme held in Rome, Italy (28 June-3 July1999) reported that Codex Alimentarius Commission has adopted a maximum level of total aflatoxins in peanuts intended for further processing at 15 ppb. On 9 September 2004 the National Agency for Drug and Food Control, Republic of Indonesia has determined that aflatoxin $\mathrm{BI}$ and total aflatoxin contents in processed peanut products should not be more than 20 and 35 ppb, respectively.

To minimize or to reduce aflatoxin contamination in peanuts, appropriate post-harvest handling methods in each level of peanut delivery chain (farmer, collector, wholesaler, and retailer) should be carried out.

The objective of this study was to obtain information on pre- and postharvest handling methods, Aspergillus flavus infection and aflatoxin BI contamination of peanuts collected from different points of the delivery chains in Cianjur regency of West Java. The moisture contents and physical quality of peanut kernels were also determined. 
Aspergillusflavus infection and aflatoxin contamination in peanuts — Okky S. Dharmaputra et al.

\section{MATERIALS AND METHODS Time and location of surveys}

Surveys were conducted during the harvest of the wet season (February 2004) at Cidaun, Naringgul and Sindangbarang districts located in Cianjur regency, and the city of Cianjur, West Java. Based on the information obtained from the Indonesian Government Regional Office for Food Crops of West Java Province, peanut production was high in Cianjur regency and it ranks second after Garut regency. Peanut production was high at Cidaun, Naringgul and Sindang Barang districts according to the information obtained from the Indonesian Government Regional Office for Food Crops of Cianjur regency.

The surveys comprised:

- interviews, using questionnaires, with farmers, collectors, wholesalers and retailers. The questionnaires consisted of questions relating to pre- and postharvest handling of peanuts.

- random sampling of various kinds of peanut products collected from farmers, collectors, wholesalers and retailers who were interviewed.

The moisture contents, physical quality of kernels, fungal (A. flavus) infection and aflatoxin B, contents from each sample were analyzed.

\section{Sampling methods}

Based on differences of storage duration, more than one peanut sample could be obtained from each farmer, collector and wholesaler. The kind of peanuts sampled included dry pods and kernels. Samples of dry pods (about $2 \mathrm{~kg}$ each) were divided three times manually and homogeneously to obtain working samples (about $250 \mathrm{~g}$ each) for analyzing moisture contents, physical quality of kernels, percentage of kernels infected by A. flavus, aflatoxin BI content, and a reserve sample. The dry peanut pods were then shelled manually.

Samples of dry peanut kernels (about $1 \mathrm{~kg}$ each) were also divided three times using a box divider to obtain working samples (about $125 \mathrm{~g}$ each) for analyzing moisture contents, physical quality of kernels, percentage of kernels infected by A. flavus, aflatoxin BI content, and a reserve sample.

\section{Moisture content, physical quality of kernels, A. flavus and aflatoxin BI analyses}

Moisture contents of kernels (based on a wet basis) were analyzed using a SINAR TM AP 6060 Moisture Analyzer. The moisture contents of some samples were confirmed using the oven method (BSI 1995). Two replicates were used from each sample. 
Physical quality of kernels was assessed in intact, shriveled and damaged kernels. The damaged kernels included cracked, broken, discoloured, and damage caused by insects or fungi. The percentage of each category of kernels was determined by counting them and dividing the total number of kernels used for physical quality analysis.

The percentage of kernels infected by A. flavus was determined using a plating method (100 kernels per sample) on Aspergillus flavus and parasiticus agar (AFPA) (P'Metal. 1983).

Aflatoxin $B_{t}$ was analyzed because it is the most dangerous toxin. Aflatoxin $B$, contents in the kernels were determined using the EL1SA method (Lee and Kennedy 2002), with two replicates used for each sample.

\section{RESULTS AND DISCUSSION Source, kind and number of samples}

At the farmer level (12 farmers), 13 samples of dry peanut pods were collected, while at collector level ( 23 collectors), 40 samples of dry pods and 7 samples of dry kernels $(1 \mathrm{~kg} / \mathrm{sample})$ were collected. At the wholesaler and retailer levels ( 2 wholesalers and 45 retailers), 5 and 45 samples of dry peanut kernels were collected, respectively. Thus, the total number of samples was 110 . Details of the peanut delivery chain, location and number of peanut samples are presented in Table 1.

Table 1. Details of the peanut delivery chain, including location and number of peanut samples

\begin{tabular}{llllc}
\hline $\begin{array}{c}\text { Peanut delivery } \\
\text { chain }\end{array}$ & $\begin{array}{c}\text { Cianjur regency/ } \\
\text { City of Cianjur }\end{array}$ & \multicolumn{1}{c}{ District } & Traditional market & $\begin{array}{c}\text { Number of } \\
\text { sample }\end{array}$ \\
\hline Farmer & Cianjur regency & Cidaun & - & 13 \\
Collector & Cianjur regency & Cidaun & - & 16 \\
& & Naringgul & - & 6 \\
& & Sindangbarang & - & 25 \\
Wholesaler & City of Cianjur & - & - & 5 \\
Retailer & Cianjur regency & - & Cipanas Market & 3 \\
& & & Sukanegara Market & 3 \\
& City of Cianjur & - & Bojong Meron Market & 10 \\
& & & Baru Market & 2 \\
& & & Muka Market & 10 \\
& & & Induk Market & 17 \\
& & & Total & 110 \\
\hline
\end{tabular}


Aspergillus flavus infection and aflatoxin contamination in peanuts - Okky S. Dharmaputra et at.

Results of interviews with farmers, collectors, wholesalers and retailers concerning pre- and postharvest handling of peanuts

Interview with farmers

The results from farmer interviews (12 respondents) are presented in Table 2. All farmers (100\%) planted a local variety of peanuts, with most of the seed sources from farmers ( $83 \%$ of respondents). Fanners harvested their peanuts at 90 to 100 days after planting. During planting, all of respondents used fertilizer, such as urea, TSP and K.C1. Weed control was conducted manually. Farmers sun-dried peanut pods for $3-4$ days. Most of the farmers used woven polypropylene bags $167 \%$ of respondents) to dry peanuts. Based on their experiences, farmers could determine when their peanuts were fully dried for safe storage. Sixty seven percent of respondents stored peanuts in woven polypropylene bags for $1-7$ days before selling to collectors. All respondents sold peanuts to collectors in the form of dry pods. Interestingly, all respondents were not aware of the aflatoxin problem in peanuts.

Table 2. Results of interviews with farmers on pre- and postharvest handling of peanuts in Cianjur regency, West Java

\begin{tabular}{|c|c|c|}
\hline No & Subject & Percentage of respondents \\
\hline 1 & $\begin{array}{l}\text { Variety of peanuts: } \\
\text { a. Local } \\
\text { b. Others }\end{array}$ & $\begin{array}{c}100 \\
0\end{array}$ \\
\hline 2 & $\begin{array}{l}\text { Seed source: } \\
\text { a. Belong to the farmers } \\
\text { b. Farmers bought seeds }\end{array}$ & $\begin{array}{l}83 \\
17\end{array}$ \\
\hline 3 & $\begin{array}{l}\text { Using fertilizer: } \\
\text { a. Yes (Urea, TSP, } \mathrm{KCl} \text { ) } \\
\text { b. No }\end{array}$ & $\begin{array}{c}100 \\
0\end{array}$ \\
\hline 4 & $\begin{array}{l}\text { Weed control: } \\
\text { a. Manually } \\
\text { b. No control }\end{array}$ & $\begin{array}{c}100 \\
0\end{array}$ \\
\hline 5 & $\begin{array}{l}\text { Harvesting time of peanuts (days after planting): } \\
\text { a. } 100 \\
\text { b. } 95 \\
\text { c. } 92 \\
\text { d. } 90\end{array}$ & $\begin{array}{c}25 \\
8 \\
8 \\
59\end{array}$ \\
\hline 6 & $\begin{array}{l}\text { When the peanuts were harvested by farmers: } \\
\text { a. Method of harvesting: } \\
\text { by pulling peanut plants manually } \\
\text { mechanically }\end{array}$ & $\begin{array}{c}100 \\
0\end{array}$ \\
\hline
\end{tabular}


Table 2. (continued)

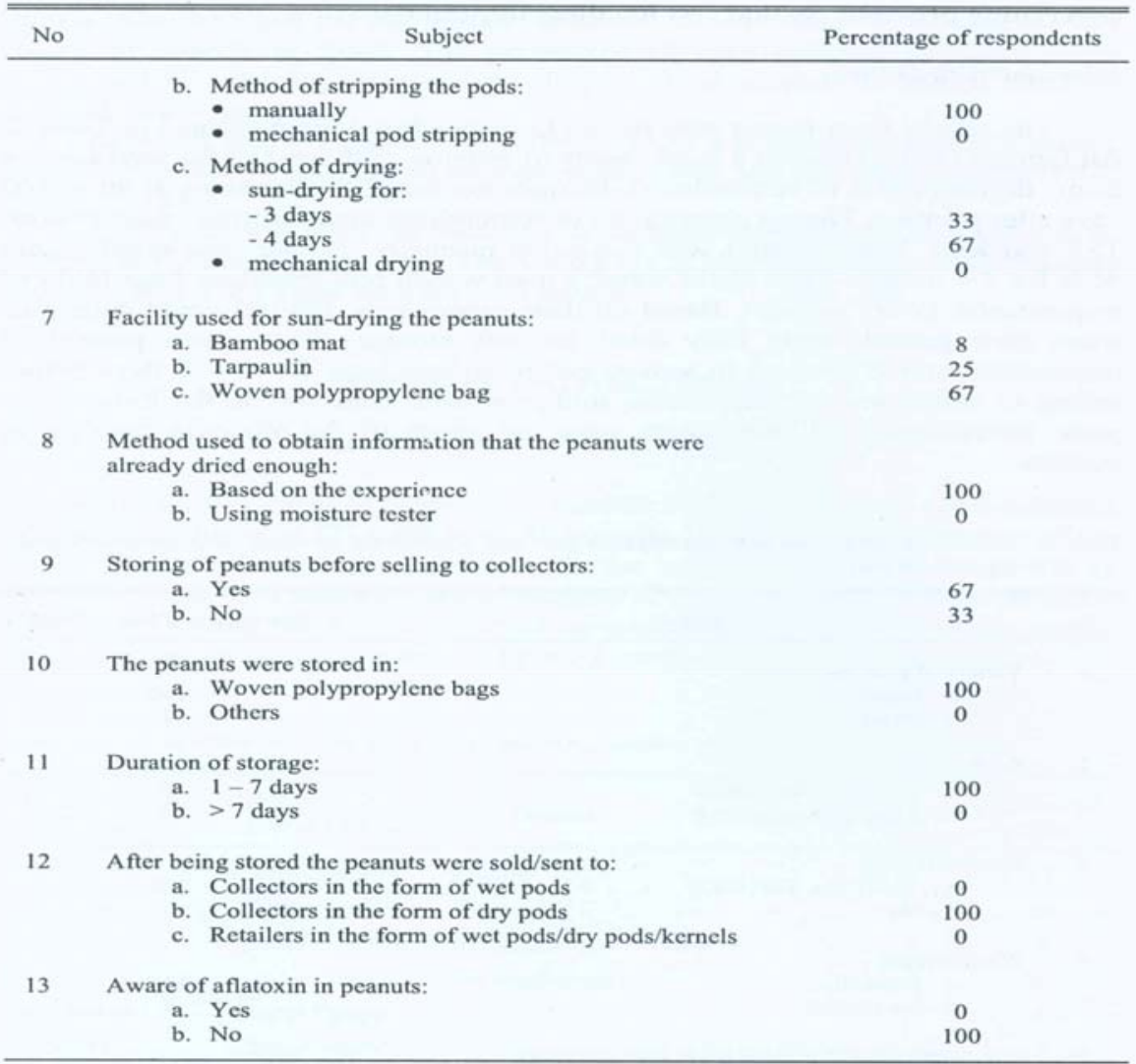

\section{Interview with collectors}

The result of interview with collectors (23 respondents) are presented in

Table 3.Based on their experience the collectors knew whether their peanuts were Fully dry. Before selling to wholesalers, peanuts were stored in woven polyPropylene bags ( $91 \%$ respondents), or by spreading them on paved floor (9\% of 
respondents) for 1-30 days. Peanuts were sold to wholesalers in the form of dry pods (35\% of respondents), or as dry pods and kernels to wholesalers and retailers (9\% of respondents) in the city of Cianjur. Peanuts were also sold to wholesalers in the form of dry pods (43\% of respondents), and to wholesalers and retailers in the form of kernels (4\% of respondents) in the big cities of West, Central and East Java. All respondents shelled peanut pods using a diesel powered sheller. Most collectors (87\% of respondents) sorted peanuts manually before selling them to wholesalers. All respondents were not aware of aflatoxin problem in peanuts.

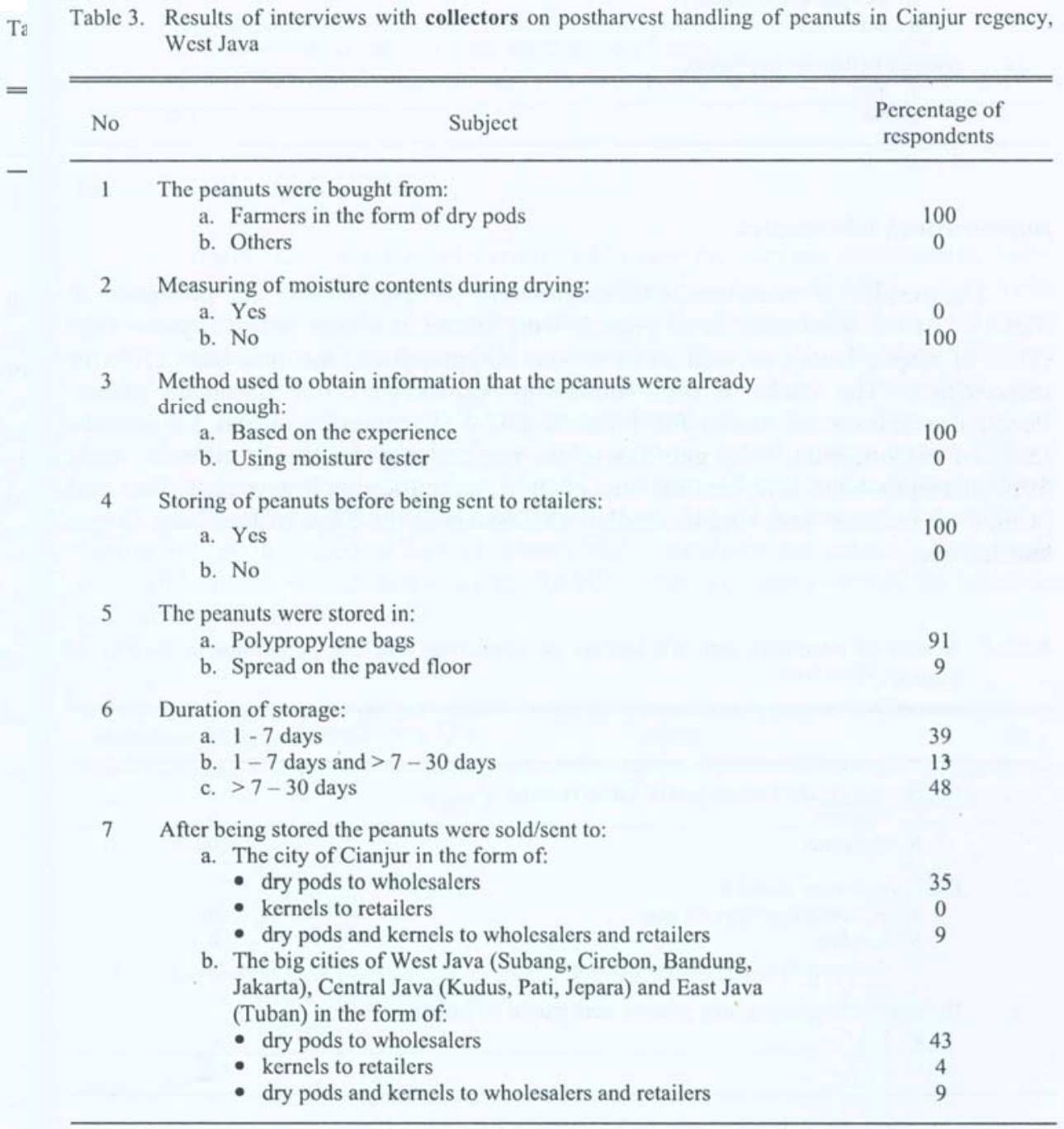


Table 3. (continued)

\begin{tabular}{ccc}
\hline \hline No & Subject & $\begin{array}{c}\text { Percentage of } \\
\text { respondents }\end{array}$ \\
\hline $8 \quad$ Method of shelling the peanuts: & \\
a. Manually & 0 \\
b. Mechanical sheller made from wood or zinc & 0 \\
c. Electric sheller & 0 \\
d. Diesel powered sheller & 100 \\
$9 \quad$ Monitoring of physical quality of peanut kernels before being sold: \\
a. Yes (sorted manually) & 87 \\
b. No & 13 \\
& Aware of aflatoxin in peanuts: & 0 \\
a. Yes & 100 \\
& b. No
\end{tabular}

\section{Interview with wholesalers}

The results of interview with wholesalers (2 respondents) are presented in Table 4. At the wholesaler level peanuts were stored in woven polypropylene bags $(50 \%$ of respondents), as well as in woven polypropylene and jute bags (50\% of respondents). The stacks of bags containing peanuts were not placed on pallets. Peanuts samples were stored for 1 month (50\% of respondents) and 1-2 months (50\% of respondents). Fifty percents of the respondents sold only peanuts, while $50 \%$ of respondents sold peanuts and other commodities such as wheat flour and peanut oil. Peanuts were sold to smaller wholesalers in the cities of Bandung, Bogor and Jakarta.

Table 4. Results of interviews with wholesalers on postharvest handling of peanuts in the city of Cianjur, West Java

\begin{tabular}{|c|c|c|}
\hline No & Subject & Percentage of respondents \\
\hline 1 & $\begin{array}{l}\text { The peanuts (in the form of pod or kernel) source: } \\
\text { a. Farmers } \\
\text { b. Collector }\end{array}$ & $\begin{array}{c}0 \\
100\end{array}$ \\
\hline 2 & $\begin{array}{l}\text { The peanuts were stored in: } \\
\text { a. Woven polypropylene bag } \\
\text { b. Jute bag } \\
\text { c. Woven polypropylene and jute bags }\end{array}$ & $\begin{array}{c}50 \\
0 \\
50\end{array}$ \\
\hline 3 & $\begin{array}{l}\text { The stack of bags containing peanuts were placed on pallets: } \\
\text { a. Yes } \\
\text { b. No }\end{array}$ & $\begin{array}{c}0 \\
100\end{array}$ \\
\hline
\end{tabular}


Table 4. (continued)

\begin{tabular}{|c|c|c|}
\hline No & Subject & Percentage of respondents \\
\hline 4 & $\begin{array}{l}\text { Storage duration of the samples } \\
\text { a. } 1 \text { month } \\
\text { b: } 2 \text { months } \\
\text { c. } 1-2 \text { months }\end{array}$ & $\begin{array}{c}50 \\
0 \\
50\end{array}$ \\
\hline 5 & $\begin{array}{l}\text { Apart from peanuts, wholesaler sold other ingredients such as: } \\
\text { a. Wheat flour and peanut oils } \\
\text { b. None }\end{array}$ & $\begin{array}{l}50 \\
50\end{array}$ \\
\hline 6 & $\begin{array}{l}\text { Peanut buyers were: } \\
\text { a. Smaller wholesalers in Bandung, Bogor and Jakarta } \\
\text { b. Others }\end{array}$ & $\begin{array}{c}100 \\
0\end{array}$ \\
\hline
\end{tabular}

\section{Interview with retailers}

The results of interview with retailers (45 respondents) are presented in Table 5. Fifty three percent of respondents bought their peanuts from wholesalers, while $47 \%$ of respondent bought peanuts from farmers and collectors. Peanuts were stored in woven polypropylene bags (71\% of respondents) and jute bags (29\% of respondents) for 1 - 7 days. Containers used at the time of sampling were rectangular plastic basins (42\% of respondents), winnowing trays (29\% of respondents), wooden boxes (18\% of respondents), round plastic basins (5\% of respondents), woven polypropylene bags ( $4 \%$ of respondents) and jute bags ( $2 \%$ of respondents). Aside from peanuts, retailers also sold other general commodities. Peanut buyers included sellers of peanut sauce products for making gado-gado, pecel and sate, as well as house wives. Retailers were also not aware of the aflatoxin problem in peanuts.

Table 5. Results of interviews with retailers on postharvest handling of peanuts in Cianjur regency and in the city of Cianjur, West Java

\begin{tabular}{ccc}
\hline \hline No & Subject & Percentage of respondents \\
\hline 1 & The peanuts source: & 22 \\
a. Farmers & 25 \\
& b. Collectors & 53 \\
& c. Wholesalers & \\
& The peanuts were stored in: & 71 \\
& a. Woven polypropylene bag & 29 \\
& b. Jute bag
\end{tabular}


Table 5. Results of interviews with retailers on postharvest handling of peanuts in Cianjur regency and in the city of Cianjur, West Java

\begin{tabular}{|c|c|c|}
\hline No & Subject & Percentage of respondents \\
\hline 3 & $\begin{array}{l}\text { Container used when peanut sampling was conducted: } \\
\text { a. Woven polypropylene bag } \\
\text { b. Jute bag } \\
\text { c. Round plastic basin } \\
\text { d. Rectangular plastic basin } \\
\text { c. Wooden box } \\
\text { f. Winnowing tray }\end{array}$ & $\begin{array}{c}4 \\
2 \\
5 \\
42 \\
18 \\
29\end{array}$ \\
\hline 4 & $\begin{array}{l}\text { Storage duration of the samples: } \\
\text { a. } 1-7 \text { days } \\
\text { b. }>7 \text { days }\end{array}$ & $\begin{array}{c}100 \\
0\end{array}$ \\
\hline 5 & $\begin{array}{l}\text { Apart from peanuts, retailers sold: } \\
\text { a. Other general commodities } \\
\text { b. Others }\end{array}$ & $\begin{array}{c}100 \\
0\end{array}$ \\
\hline 6 & $\begin{array}{l}\text { Peanut buyers were: } \\
\text { a. gado-gado, pecel and sate sellers and house wives } \\
\text { b. Others }\end{array}$ & $\begin{array}{c}100 \\
0\end{array}$ \\
\hline
\end{tabular}

Moisture contents, physical quality of kernels, the incidence of $A$. flavus and aflatoxin contamination

\section{Moisture contents}

According to Diener and Davis (1969) moisture content is an important factor affecting the growth of $A$. flavus and aflatoxin production.

The range and mean moisture contents of kernels derived from various kinds of peanuts collected from farmers, collectors, wholesalers and retailers are presented in Table 6 and Figure 1. The moisture contents of kernels collected from farmers was relatively similar to those collected from collectors and retailers, while the moisture contents of kernels collected from wholesalers was the lowest. This was due to the storage duration of peanuts at farmer and collector levels which were relatively shorter than those at the wholesaler level (Tables 2, 3 and 4). The moisture contents of kernels were always in equilibrium with the relative humidity of storage room.

The range and mean moisture contents of kernels derived from various kinds of peanuts and collected from farmers, collectors, wholesalers and retailers were 5.9 9.9\% and 8.4\%; $7.8-9.6 \%$ and $8.7 \%$; $8.1-9.4 \%$ and $8.9 \%$; $6.2-8.8 \%$ and $7.5 \%$; $6.5-9.3 \%$ and $8.5 \%$, respectively (Table 6). In general, the mean of moisture content of peanut kernels in each delivery chain were considered safe for storage. SNI (1995) determined that the safe moisture contents for storage of peanut pods and kernels were 9 and 8\%, respectively. 
Aspergillus flavus infection aflatoxin contamination in peanuts - Okky S. Dharmaputra et al

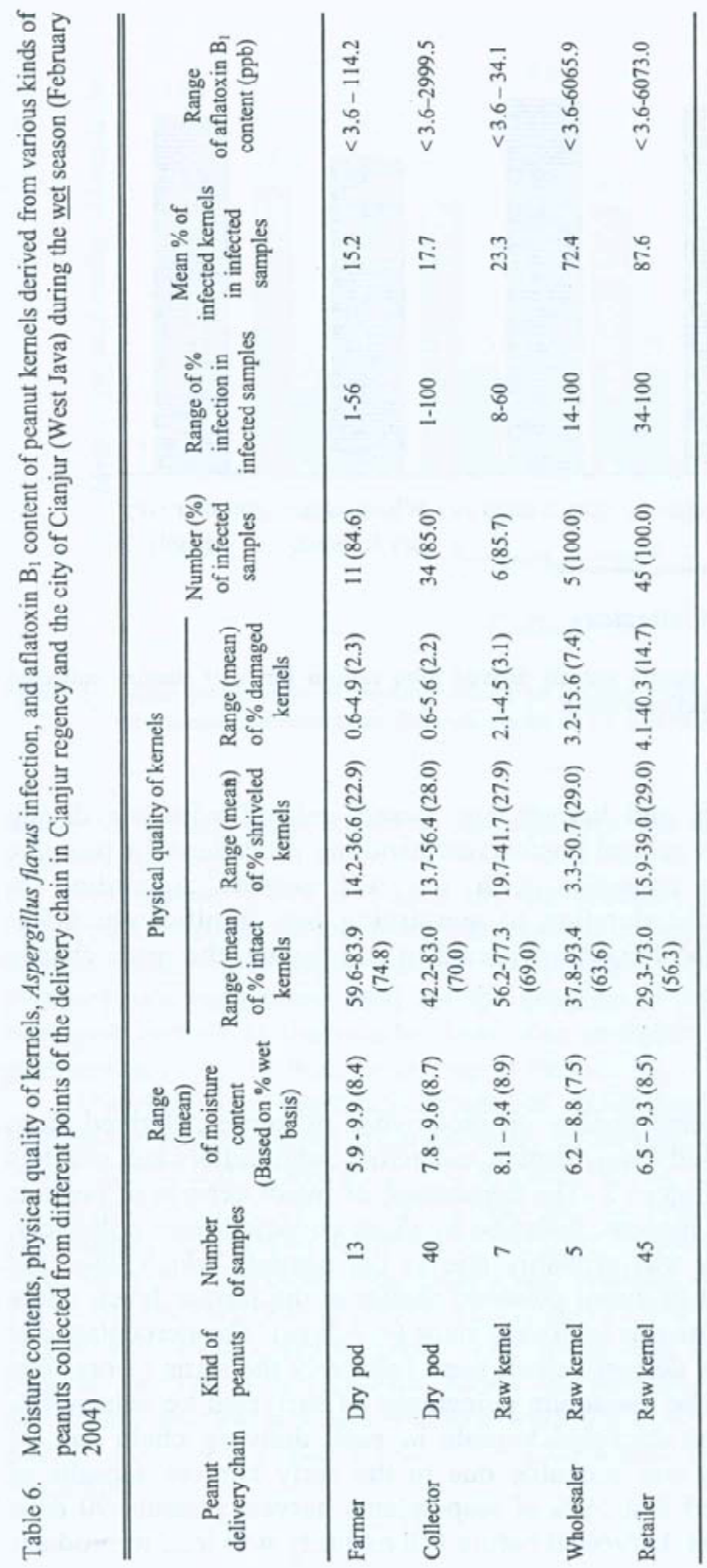




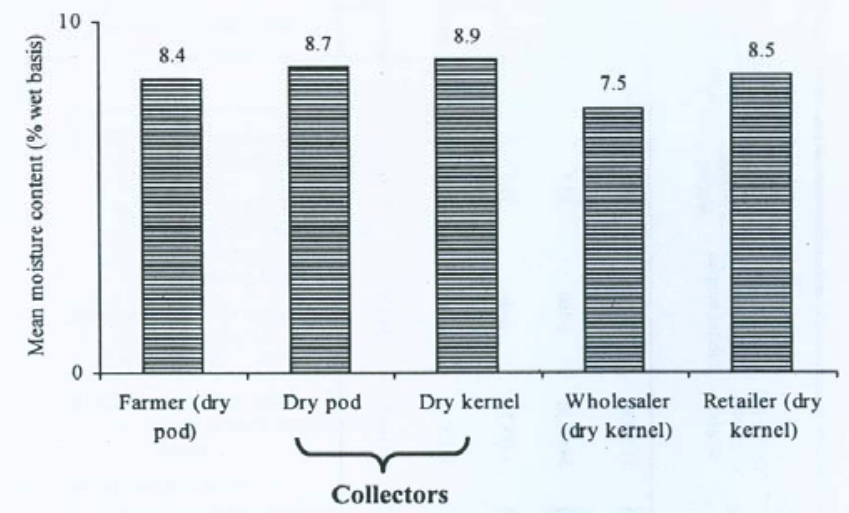

Figure 1. Mean moisture contents of peanut kernels derived from various kinds of peanuts collected from different points of the delivery chain.

Moisture content of pods and kernels are closely related with the drying process. Sun-drying is the most critical postharvest handling procedure for peanuts, especially when the harvest coincides with the wet season. According to Wongvirajtana et al. (1993) the duration of sun-drying can significantly affect fungal growth in grains, with the longer the period of sun-drying, the more chance for the fungi to infect the grains.

\section{Physical quality of kernels}

Range and mean of physical quality characteristics of kernels derived from various kinds of peanuts collected from farmers, collectors, wholesalers and retailers are presented in Table 6, and Figure 2. The percentage of intact kernels of peanuts collected from farmers was the highest, followed by those collected from collectors, wholesalers and retailers. This was probably due to the peanuts which have not being shelled using mechanical or diesel powered sheller at the farmer level, while the duration of storage of peanuts was relatively short ( $<7$ days). The percentages of shriveled kernels in each of the delivery chain were relatively the same (more than 22\%). SNI (1995) determined the maximum percentage of shriveled kernels is $4 \%$, consequently the percentage of shriveled kernels in each delivery chain can be categorized as very high. This was probably due to the early harvest. Results of interviews with farmers showed that $59 \%$ of respondents harvest peanuts 90 days after planting (Table 2). Peanuts harvested before full maturity will tend to produce 


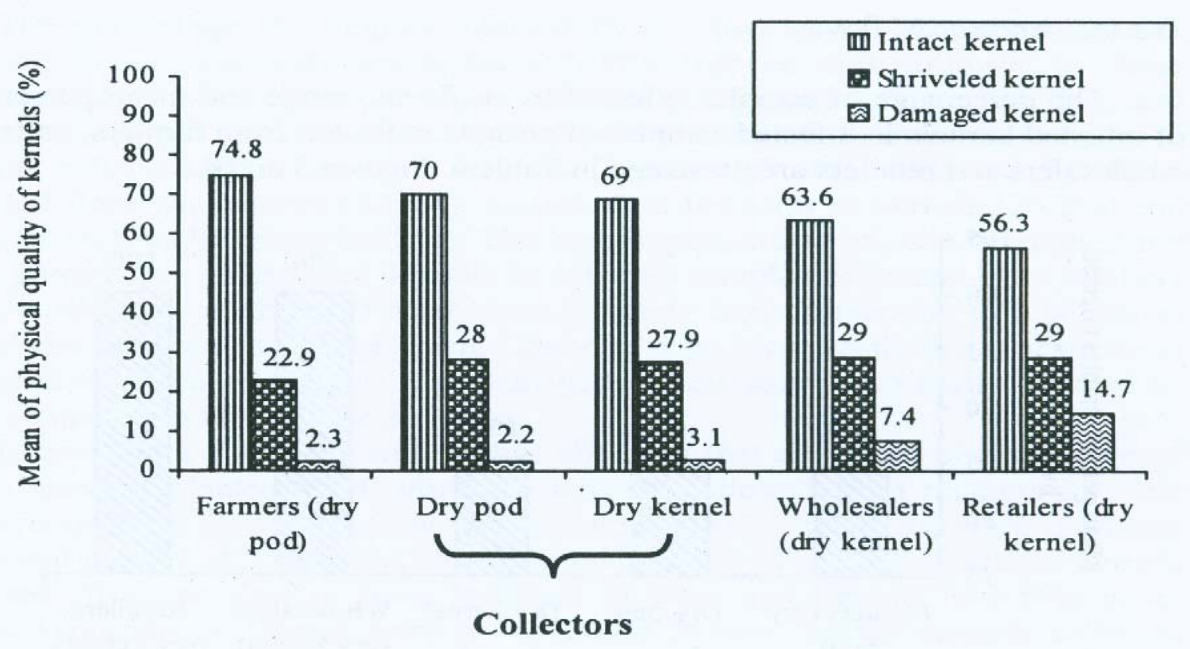

Figure 2. Mean percentages of physical quality of kernels. Peanut samples derived from various kinds of peanuts collected from different points of the delivery chain.

shriveled kernels after drying, consequently the kernels could be more easily infected by fungi.

The percentage of damaged kernels collected from retailers was the highest, followed by that collected from wholesalers, collectors and farmers. The damaged kernels could have been caused by insects, rodents and fungal attacks, and inappropriate equipment used for the shelling of pods. The highest percentage of damaged kernels at the retailer level was probably due to the longer duration of postharvest handling from farmer up to the retailer.

The range and mean percentages of intact kernels derived from various kinds of peanuts and collected from farmers, collectors, wholesalers and retailers were 59.6 - 83.9\% and 74.8\%; 42.2 83.0\% and 70.0\%; 56.2 - 77.3\% and 69.0\%; $37.8-93.4 \%$ and $63.6 \%$; $29.3-73.0 \%$ and $56.3 \%$, respectively. The range and mean-percentages of shriveled kernels derived from various kinds of peanuts and collected from farmers, collectors, wholesalers and retailers were $14.2-36.6 \%$ and 22.9\%; 13.7 - 56.4\% and 28.0\%; $19.7-41.7 \%$ and 27.9\%; $3.3-50.7 \%$ and $29.0 \%$; $15.9-39.0 \%$ and $29.0 \%$, respectively. The range and mean percentages of damaged kernels derived from various kinds of peanuts and collected from farmers, collectors, wholesalers and retailers were 0.6 - 4.9\% and 2.3\%; 0.6 - 5.6\% and 2.2\%; 2.1 - 4.5\% and 3.1\%; 3.2 - 15.6\% and 7.4\%; 4.1 - 40.3\% and $14.7 \%$, respectively. 
The incidence o/A. flavus

The percentage of samples infected by A. flavus, range and mean percentages of infected kernels in infected samples of peanuts collected from farmers, collectors, wholesalers and retailers are presented in Table 6, Figures 3 and 4.

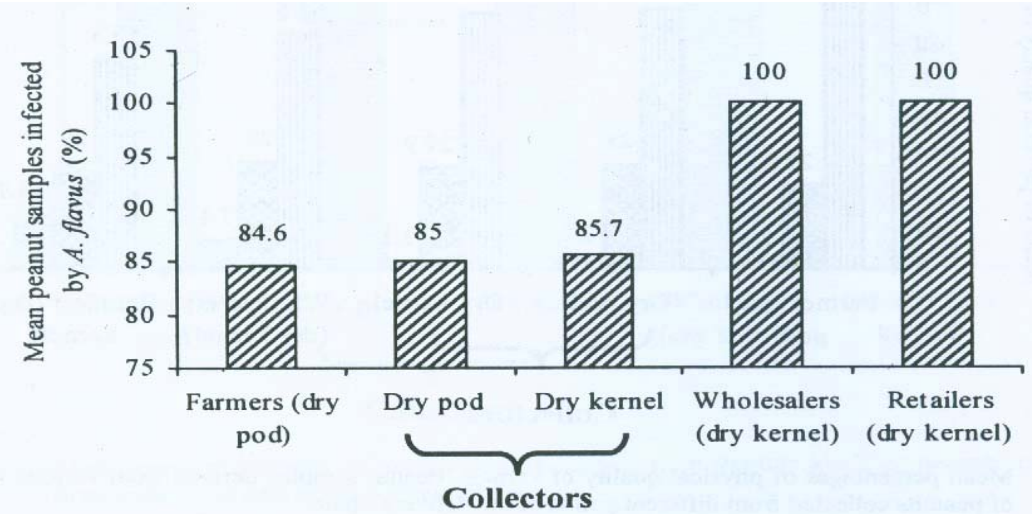

Figure 3. Mean percentages of peanut samples infected by A. flavus. Peanut samples derived from various kinds of peanuts collected from different points of the delivery chain.

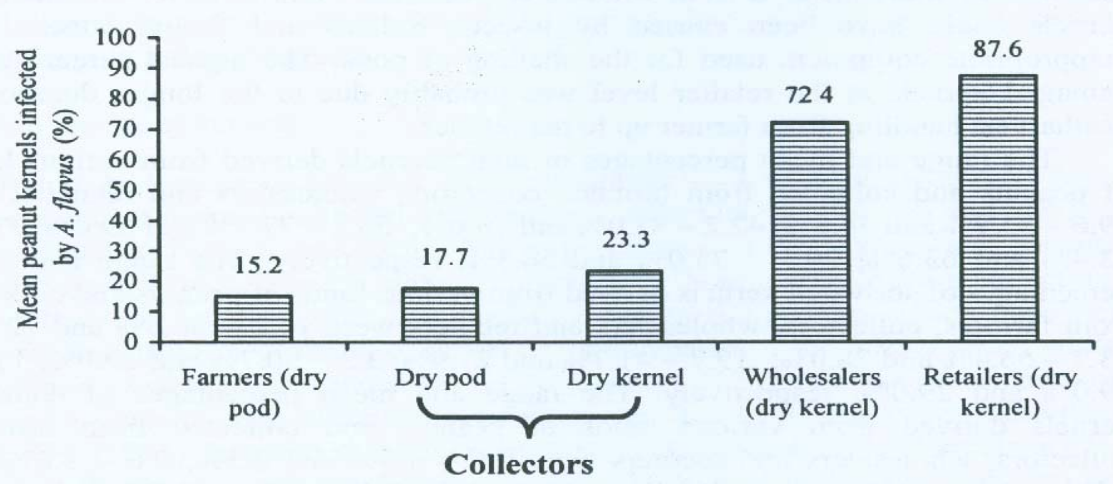

Figure 4. Mean percentages of kernels infected by A. flavus in infected samples. Peanut samples derived from various kinds of peanuts collected from different points of the delivery chain. 
Aspergillus flaws infection and aflatoxin contamination in peanuts - Okky S. Dharmaputra et al.

The percentage of samples infected by A. flavus was highest in peanuts collected from wholesalers and retailers ( $100 \%$, respectively), followed by those collected from collectors in the form of pods (85\%) and kernels (85.7\%), and farmers (84.6\%). The mean percentage of infected kernels in infected samples of peanuts collected from retailers was the highest (87.6\%), followed by those collected from wholesalers (72.4\%), collectors in the form of kernels (23.3\%) and pods (17.7\%), and farmers (15.2\%). The highest percentage of peanut samples and mean percentages of infected kernels in infected samples collected from retailers was related to the methods of postharvest handling from farmers up to retailers, as well as the duration of storage. Peanut kernels were more easily infected by fungi compared to unshelled peanuts. The damaged kernels were more easily infected by fungi compared to intact kernels.

Dharmaputra and Retnowati (1996) observed that the range in percentage of peanut kernels infected by A. flavus in samples collected from retailers in some locations in West Java during the wet season was 83 - 100\%. Aspergillus flavus was found in 98\% of 256 peanut kernel samples and in $61 \%$ of all examined kernels collected from retailers in some locations in West and Central Java (Pitt e? al. 1998). According to Dharmaputra et al. (2003) 24 raw kernel samples collected from retailers in traditional markets located in Bogor, Pati, Yogyakarta and Malang were 100\% infected with $A$. flavus during both the wet and dry seasons, respectively. Dharmaputra et al. (2005) also reported that 98 and $100 \%$ of 54 raw peanut kernel samples collected from retailers during the wet and dry seasons in Wonogiri regency, West Java, were infected by A. flavus, respectively.

\section{Aflatoxin B: contamination}

The range of aflatoxin $\mathrm{B}$ | contents in peanut kernels derived from various kinds of peanuts and collected from farmers, collectors, wholesalers and retailers is presented in Table 6. The range of aflatoxin $\mathrm{B}$, contents in peanut samples collected from retailers $(<3.6-6073.0 \mathrm{ppb})$ was the widest, but almost similar to those collected from wholesalers ( $<3.6-6065.9 \mathrm{ppb})$.

The percentage of samples contaminated with different levels of aflatoxin $B \mid$ is shown in Table 7. In Australia the maximum allowable limit of aflatoxin in peanut and peanut products is $15 \mathrm{ppb}$ (QDPI 2000). The percentage of samples contaminated with more than $15 \mathrm{ppb}$ of aflatoxin Bj was highest in peanuts collected from wholesalers (80\% of samples), followed by retailers $(75.6 \%)$, farmers (38.5\%) and collectors in the form of pods and kernels (30.0 and 14.3\%, respectively), although the highest percentage of samples infected by A. flavus was found in peanuts collected from retailers, followed by those collected from wholesalers, collectors and farmers. This may have been associated with differences in the existence of toxigenic strains of A. flavus. According to Pitt and Hocking (1997) aflatoxin production depends on the toxigenicity of strains of A. flavus. The presence of antagonistic fungi to toxigenic $A$. flavus could also inhibit aflatoxin production. Dharmaputra et al. (2001) reported that $A$. niger was the most promising 
antagonistic fungus to toxigenic strains of $A$. flavus, because it inhibited aflatoxin production up to $80 \%$ under in vitro conditions. The percentages of peanut samples infected by $A$. niger at farmer, collector, wholesaler and retailer levels in Cianjur regency were 69.2, 80 and $85.7,60$ and $76.5 \%$, respectively.

Table 7. Number and percentage of peanut samples derived from various kinds of peanuts collected from different points of the delivery chain in Cianjur regency and the city of Cianjur (West Java) during the wet season (February 2004), and contaminated with different levels of aflatoxin $\mathrm{B}_{1}$.

\begin{tabular}{|c|c|c|c|c|c|}
\hline \multirow{3}{*}{$\begin{array}{c}\text { Aflatoxin } B_{1} \\
\text { contents (range } \\
\text { in ppb) }\end{array}$} & \multicolumn{5}{|c|}{ Number (\%) of peanut samples contaminated with aflatoxin $B_{1}$} \\
\hline & \multirow{2}{*}{$\begin{array}{l}\text { Farmer - } \\
\text { Dry pod }\end{array}$} & \multicolumn{2}{|c|}{ Collector } & \multirow{2}{*}{$\begin{array}{c}\text { Wholesaler - } \\
\text { Kernel }\end{array}$} & \multirow{2}{*}{$\begin{array}{c}\text { Retailer - } \\
\text { Kernel }\end{array}$} \\
\hline & & Dry pod & Kernel & & \\
\hline$\leq 5$ & $5(38.4)$ & $15(37.5)$ & $5(71.4)$ & $1(20.0)$ & $10(22.2)$ \\
\hline$>5 \leq 15$ & $3(23.1)$ & $13(32.5)$ & $1(14.3)$ & 0 & $1(2.2)$ \\
\hline$>15 \leq 50$ & $3(23.1)$ & $3(7.5)$ & $1(14.3)$ & 0 & $4(8.9)$ \\
\hline$>50 \leq 100$ & $1(7.7)$ & $1(2.5)$ & 0 & $1(20.0)$ & $2(4.4)$ \\
\hline$>100 \leq 500$ & $1(7.7)$ & $4(10.0)$ & 0 & 0 & $16(35.6)$ \\
\hline$>500 \leq 1000$ & 0 & $3(7.5)$ & 0 & 0 & $5(11.1)$ \\
\hline$>1000$ & 0 & $1(2.5)$ & 0 & $3(60.0)$ & $7(15.6)$ \\
\hline
\end{tabular}

At the farmer level, no sample was contaminated with aflatoxin $\mathrm{Bj}$ at more than $1000 \mathrm{ppb}$. At the collector, wholesaler and retailer levels, 1 sample $(2.5 \%$ of collected samples), 3 samples ( $60 \%$ of collected samples) and 7 samples ( $15.6 \%$ of collected samples) contained more than $1000 \mathrm{ppb}$ of aflatoxin BI, respectively. At the collector level, aflatoxin $\mathrm{BI}$ content in one sample was $3000 \mathrm{ppb}$. The highest aflatoxin BI content measured at the wholesaler and retailer level was $6066 \mathrm{ppb}$ (in one sample) and $6073 \mathrm{ppb}$ (in one sample), respectively. Pitt and Hocking (1996) concluded that more than $1000 \mathrm{ppb}$ of aflatoxin could cause acute toxic both in humans and animals.

Although the percentage of samples contaminated with aflatoxin B i exceeding $15 \mathrm{ppb}$ at the farmer level (38.5\%) was higher than that at the collector level (30\%), aflatoxin BI contents more than $500 \mathrm{ppb}$ were found in 4 peanut samples collected from collectors, while the highest aflatoxin B] content at farmer level was $114.2 \mathrm{ppb}$. This results showed that aflatoxin BI contents at the collector level are generally higher than at the farmer level, probably because the duration of storage at the collector level was longer, and under poorer storage conditions compared to that at the farmer level (Tables 2 and 3).

At the farmer level, 2 peanut samples were not infected by $A$. flavus, but they were contaminated with aflatoxin B, (Table 6). It was therefore assumed that these peanuts were infected by $A$. flavus before harvest, or during sun-drying, and contaminated with aflatoxin $B$ ! during sun-drying. Further sun-drying, and in the presence of antagonistic fungi to $A$. flavus, could inhibit or kill $A$. flavus. Therefore, 
aAspergillus flavus infection and aflatoxin contamination in peanuts - Okky S. Dharmaputra et al.

no A. flavus was isolated using AFPA media, but aflatoxin B, still existed. Buchi and Rae (1969) found that aflatoxin could only be degraded at $268-269^{\circ} \mathrm{C}$.

\section{CONCLUSIONS}

In Cianjur regency farmers dried (sun-drying) peanut pods until safe moisture contents were obtained, and sold peanuts to collectors in the form of dry pods. In general, farmers stored peanuts in woven polypropylene bags for 1 - 7 days before selling to collectors. Collectors sold the peanuts to wholesalers and retailers in the form of dry pods and kernels. Collectors shelled the peanut pods using diesel powered shellers. At the wholesaler level, peanuts were stored in woven polypropylene and jute bags. In general, stacks of bags containing peanuts were not placed on pallets. Retailers stored peanuts in woven polypropylene and jute bags for $1-7$ days. Most retailers used rectangular plastic basins as containers when the peanut sampling was being conducted, followed by winnowing trays, wooden boxes, round plastic basins, woven polypropylene bags and jute bags.

The mean moisture contents of peanut kernels derived from various kinds of peanuts in each part of the delivery chain were considered to have safe moisture contents. The percentages of intact peanut kernels collected from farmers was the highest, followed by those collected from collectors, wholesalers and retailers. The percentages of shriveled kernels collected from different parts of the delivery chains were relatively similar. The percentage of damaged kernels collected from retailers was the highest, followed by that collected from wholesalers, collectors and farmers.

The percentages of samples infected by A. flavus in peanuts collected from wholesalers and retailers were the highest (100\%, respectively), followed by those collected from collectors and farmers. The mean percentages of infected kernels in infected samples collected from retailers were the highest, followed by those collected from wholesalers, collectors and farmers.

The range of aflatoxin BI contents in peanut samples collected from retailers $(<3.6$ $6073.0 \mathrm{ppb})$ was the widest, but almost similar with that collected from wholesalers $(<3.6$ $6065.9 \mathrm{ppb}$ ). The percentage of samples contaminated with more than $15 \mathrm{ppb}$ of aflatoxin B) collected from wholesalers $(80.0 \%$ of samples) was the highest, followed by retailers (75.6\%), farmers (38.5\%) and collectors in the form of pods and kernels (30.0 and 14.3\%, respectively).

Our results show that postharvest handling methods employed prior to peanuts being delivered to wholesalers and retailers will have a severe impact on the level of aflatoxin contamination in peanuts in different parts of the delivery chain. Postharvest handling methods that minimize kernel infection by $A$. flavus and aflatoxin contamination, especially at wholesalers and retailers in traditional markets should be employed to minimize aflatoxin contamination for Indonesian peanut consumers. 


\section{ACKNOWLEDGEMENTS}

The authors gratefully acknowledge the financial support of the Government of Indonesia. Thanks are due to the Indonesian Government Regional Office for Food Crops of West Java Province, Head and staff of the Indonesian Government Regional Office for Food Crops of Cianjur regency, especially to Mr. Jayanudin for the information given relating to the survey; Head and staff of the Indonesian Government Subregional Office for Food Crops at Cidaun, Naringgul and Sindangbarang districts, Cianjur regency, for their cooperation during the survey; to Drs. Ivan R. Kennedy and Nanju Alice Lee of the University of Sydney, Australia; to Prof.Dr. Rizal Syarief and Dr. Graeme Wright who have reviewed this article; and to the technicians of the Laboratory of Plant Pathology, SEAMEO BIOTROP; Mr. Faizal Arifin Nur Akbar and Mr. Pujo Waluyo for their assistance.

\section{REFERENCES}

BSI. 1995. Oilseeds-determination of moisture and volatile matter content. British Standard International. (Supplement).

Buchi, G. and I.D. Rae. 1969. The structure and chemistry of the aflatoxins. In Goldblatt, L.A. (Ed). Aflatoxins: Scientific Background, Control and Implications. Academic Press, New York. p. 55 -

75.

Dhartnaputra, O.S and I. Retnowati. 1996. Fungi isolated from groundnuts in some locations of West Java. BIOTROPIA No. 9: 15 - 25.

Dharmaputra, O.S., A.S.R.Putri, I. Retnowati and S. Ambarwati. 2001. Soil mycobiota of peanut fields in Wonogiri regency, Central Java: their effect on the growth and aflatoxin production of Aspergillus flavus in vitro. BIOTROPIA No. 17: 30 - 56.

Dharmaputra, O.S., I. Retnowati, A.S.R. Putri and S. Ambarwati. 2003. Aspergillus flavus and aflatoxin in peanuts at various stages of the delivery chain in Pati regency, Central Java. Paper presented at the $3^{\text {rd }}$ APEC/ $21^{\text {st }}$ ASEAN Postharvest Technology Seminar. Nusa Dua, Bali, 23 - 26 August 2003.

Dharmaputra, O.S., I. Retnowati, A.S.R.Putri and S. Ambarwati. 2005. Aspergillus flavus infection and aflatoxin contamination in peanuts at various stages of the delivery chain in Wonogiri regency, Central Java, Indonesia. Paper presented at the International Peanut Conference. Bangkok, 9-12 January 2005.

Diener, U.L. and N.D. Davis. 1969. Aflatoxin formation by Aspergillus flavus. In Goldblatt, L.A. (Ed). Aflatoxins: Scientific Background, Control, and Implications. Academic Press, New York. p. 13-54.

Lee, N.A. and I.R. Kennedy. 2002. ELISA Workshop Analysis of Aflatoxin B, in Peanuts. SEAMEO BIOTROP, Bogor, 12-13 February 2002.

Lubulwa, A.S.G. and J.S. Davis. 1994. Estimating the social costs of the impacts of fungi and aflatoxins in maize and peanuts. In Highley, E., E.J. Wright, H.J. Banks and B.R. Champ. (Eds). Stored Product Protection. Vol. 2. Proceedings of $6^{\text {th }}$ International Working Conference on Stored-product Protection. Canberra, 17-23 April 1994. CAB International, Wallingford. p. 1017 - 1042. 
Aspergillus flavus infection and aflatoxin contamination in peanuts - Okky S. Dharmaputra et al.

Pitt, J.I., A.D. Hocking and D.R. Glenn. 1983. An improved medium for the detection of Aspergillus flavus and A. parasiticus. Journal Appl. Bacteriology 54: 109-114.

Pitt, J.I. and A.D. Hocking. 1996. Current knowledge of fungi and mycotoxins associated with food commodities in Southeast Asia In Highley, E. and G.I. Johnson. (Eds). Mycotoxin Contamination in Grains. ACIAR Technical Reports 37, Canberra, p. 5 - 10.

Pitt, J.I. and A.D. Hocking. 1997. Fungi and Food Spoilage. Blackie Academic and Professional, London.

Pitt, J.I., A.D. Hocking, B.F. Miscamble, O.S. Dharmaputra, K.R. Kuswanto, E.S. Rahayu and Sardjono. 1998. The mycoflora of food commodities from Indonesia. Journal of Food Mycology I (1): 41 -60.

QDPI. 2000. Aflatoxin in Peanuts; Tips to Reduce the Risk. Crop Link. Queensland Department of Primary Industries and Fisheries, Farming Systems Institute, Kingaroy. (See www.qld.gov.au/ fieldcrops/3027.html).

Standar Nasional Indonesia (SNI). 01-39219-1995. 1995. Kacang Tanah. Dewan Standardisasi Nasional, Jakarta.

Wongvi raj tana, P., S. Soponronnarit and A. Nathakaranakule. 1993. Feasibility study of in-store corn drying under tropical climates. In Naewbanij, J.O., A.A. Manilay and A.S. Frio (Eds). Increasing Handling, Processing and Marketing Efficiency in the Grain Postharvest System. Proceedings of the $16^{\text {h }}$ ASEAN Seminar on Grain Postharvest Technology. Phuket, 24 - 26 August 1993. ASEAN Grain Postharvest Programme, Bangkok, p. 265 - 283. 